\title{
PENGEMBANGAN KOMUNITAS PESISIR DI KECAMATAN LEITIMUR SELATAN DENGAN MEMANFAATKAN KEARIFAN LOKAL
}

\author{
Richard A. de FRETES \\ e-mail: rdefretes@yahoo.com \\ Jurusan Teknik Industri, Universitas Pattimura, Kampus Poka, Ambon, 97233, Indonesia \\ Dosen Program Studi Teknik Industri, Fakultas Teknik, Universitas Pattimura
}

\begin{abstract}
ABSTRAK
Kecamatan Leitisel merupakan wilayah yang potensi sumber daya pesisir yang belum dioptimalkan dengan baik. Masyarakat didaerah ini sebagaian besar merupakan masyarakat yang homogen (masyarakat asli) dengan ciri yang multikultur, dengan keanekaragaman social budaya yang tinggi. Analisis data yang digunakan dalam analisis kualitatif adalah pengujian statistic dengan : Uji Chi-Square, Uji korelasi Rank Spearman, Analisis Varian dan analisis Jalur. Setelah persyaratan normalitas data maka dilakukan analisis linear berganda (Path analysis). Guna menganalisis model pengembangan masyarakat pesisir maka dilakukan analisa SWOT. Hasil penelitian menunjukan bahwa terdapat hubungan yang nyata antara keragaan individu dengan perilaku dalam mengelola SDP. Implementasi pengembangan masyarakat pesisir Leitisel menuju masyarakat yang sejahtera melalui pengelolaan SDP secara optimal dapat akselerasi dengan dibangunnya visi, dilaksanakannya misi, ditetapkannya tujuan yang jelas serta strategi penyuluhan yang tepat tentang pengelolaan SDP. Perilaku masyarakat pesisir Leitisel dalam mengelola SDP secara optimal dapat berkontribusi terhadap kesejahteraan. Visi, misi, tujuan dan target penyuluhan dalam kaitannya dengan pengelolaan SDP sangat penting dipahami, dijadikan motivator dalam bertindak, dan dilaksanakan dengan penuh tanggungjawab oleh segenap pemanfaat SDP, yaitu nelyan, atau komunitas pesisir lain, pemerintah, dan swasta. Komunitas local menjalankan kegiatan perikanan yang tidak merusak lingkungan, secara ekonomi menguntungkan dan secara social mampu meningkatkan kualitas kehidupan berkeluarga, berkelompok dan bermasyarakat. Nelayan hendaknya mampu melakukan perencanaan usaha, memperkirakan hasil, menjamin terserapnya produk dipasar, dan mengawasi jalannya usaha.
\end{abstract}

Kata kunci : Masyarakat pesisir, SWOT, Sumber Daya Perairan.

\section{PENDAHULUAN}

Masalah Indikator ketertinggalan Kecamatan Letisel salah satunya adalah indicator pendapatan masyarakat yang terdiri dari indicator pengeluaran konsumsi perkapita dan angka kemiskinan yang masih tinggi (RPJMN 2015 - 2019). Hal ini disebabkan karena sumberdaya unggulan daerah belum dimanafaatkan dan dikelola dengan baik. Oleh karena itu dibutuhkan upaya pengembangan komunitas pesisir dengan memanfaatkan kearifan lokal. Pengembangan dan pengelolaan industri melibatkan banyak variable, namun dalam penelitian ini hanya dibatasi pada inventarisasi potensi sumberdaya alam pesisir unggulan wilayah sebagai input untuk menghasilkan suatu barang jadi atau setengah jadi.

Suatu Penelitian difokuskan pada analisis perilaku masyarakat pesisir mengelola SDP berdasarkan nilai-nilai social budaya setempat. Penelitian ini mencakup sembilan peubah penelitian sebagai berikut :

1. Dinamika social masyarakat $\left(\mathrm{X}_{1}\right)$

2. Kualitas kepemimpinan masyarakat $\left(\mathrm{X}_{2}\right)$
3. Pengelola usaha pesisir dan laut $\left(X_{3}\right)$

4. Kualitas program pemberdayaan masyarakat $\left(\mathrm{X}_{4}\right)$

5. Kompetensi fasilitator program pemberdayaan $\left(\mathrm{X}_{5}\right)$

6. Kualitas pendukung kegiatan perikanan $\left(\mathrm{X}_{6}\right)$

7. Perilaku masyarakat pesisir memanfaatkan SDP $\left(\mathrm{Y}_{1}\right)$

8. Kualitas pengelolaan $\operatorname{SDP}\left(\mathrm{Y}_{2}\right)$

9. Kesejahteraan rumah tangga $\left(\mathrm{Y}_{3}\right)$

\section{KAJIAN TEORI DAN METODE}

\subsection{Wilayah dan Masyarakat Pesisir}

Wilayah pesisir merupakan daerah peralihan anatara ekosistem darat dan laut (Departemen Kelautan dan Perikanan,2002 b). Wilayah pesisir mencakup daerah kea rah darat yang masih terkena pengaruh percikan air laut atau pasang surut, dan kearah laut meliputi paparan benua ( Beatley dkk.,1994).

Masyarakat pesisir sebagai sebuah kumpulan komunitas memiliki struktur soaial yang khas yang dicirikan oleh adanya pola hubungan interaksi antara anggota masyarakat satu dan lainnya. 


\subsection{Permasalahan Masyarakat Pesisir}

Permasalahan utama nelayan adalah pola pendapatan yang tidak teratur dan fluktuatif. Kegiatan kenelayanan lebih banyak dihadapkan pada resiko dan ketidakpastian sehingga nelayan tidak memiliki gambaran tentang pendapatan yang diperoleh dari satu kali penangkapan.

\subsection{Peraturan Pengelolaan Sumber Daya Pesisir}

Degradasi lingkungan dan multikonflik lingkungna pesisir memicu diperlukannya suatu strategi pengelolaan pesisir. Selain peraturan-peraturan formal yang dikelurkan oleh pemerintah, ada peraturan pengelolaan sumber daya perikanan oleh masyarakat sebagai suatu bentuk kearifan local. Pengelolaan oleh masyarakat bermakna bahwa masyarakat memiliki wewenang dan tanggungjawab mengelola sumber daya perikanannya sendiri.

\subsection{Orientasi Nilai Budaya dan Kepemimpinan}

Kepemimpinan berperan mendorong masyarakat untuk menerapkan aturan-aturan di lingkungannya. Kepemimpinan menurut Terry, adalah kemampuan (pemimpin atau leader/s) untuk mempengaruhi orang lain yakni orang yang dipimpin atau pengikutpengikutnya sehingga orang lain tersebut bertingkah laku sebagaimana dikehendaki oleh pemimpin tersebut.

\subsection{Penyuluhan dan Pengembangan Pola Perilaku}

Penyuluhan merupakan proses perubahan berencana yang berkesinambungan, mencakup kegiatan pembelajaran bagi individu, kelompok, organisasi, komunitas, hingga masyarakat yang lebih luas mengelola transformasi situasi melalui perubahan perilaku. Sebuah system pendidikan, pelaksanaan penyulihan harus memahami filosofi pendidikan, yakni falsafah pentingnya individu, falsafah membantu diri sendiri, falsafah menddidik, falsafah demokrasi, falsafah bekerjasama, dan falsafah kontinyuitas.

\subsection{Teori dan Konsep Perilaku}

Perilaku adalah tanggapan atau reaksi individu terhadap rangsangan atau lingkungan (Pusat Bahasa Depdiknas 2003 ). Model perilaku dapat digunakan untuk menjelaskan proses pengembangan sumber daya manusia ( Salkind, 1985). Unsur perilaku dapat dikelompokan menjadi tiga hal, yaitu :
1) Pengetahuan (kognitif)
2) Ketrampilan (psikomotorik).
3) Sikap mental (afektif)

\section{Motivasi dan Perilaku}

Motivasi adalah proses mendorong, mengarahakan, dan memelihara perilaku manusia untuk mencapai suatu tujuan.

\subsection{Pembangunan Masyarakat dan Konsep Pemberdayaan}

Pembangunan nasiaonal memiliki tiga dimensi yakni, dimensi ekonomi, politik dan social sehingga perlu dilakukan secara berimbang dan mensejahterakan. Setiap upaya pembangunan ditujukan untuk masyarakat, yang bertujuan membina hubungan dan kehidupan setiap orang dalam hidup bermasyarakat, tetapi bertujuan pula membangun masyarakat karena setiap satuan masyarakat memiliki kekuatan sendiri (Ndraha, 1990).

\section{TUJUAN DAN MANFAAT PENELITIAN}

\subsection{Tujuan Penelitian.}

a. Mengidentifikasi dan potensi sumberdaya alam pesisir sebagai input.

b. Menelaah ciri spesifik komunitas pesisir.

c. Menganalisis perilaku masyarakat pesisir menuju tata kehidupan yang lebih baik.

d. Memberikan gambaran rencana tahapan dari pengembangan SDP pada Kecamatan Letimur Selatan kepada Pemerintah Kota Ambon.

e. Hasil penelitian diharapkan dapat dipublikasi melalui jurnal nasional yang memiliki ISSBN, dan sebagai masukan kepada Pemda Kota Ambon dalam mengusulkan rekomendasi pengembangan SDP.

f. Memperkaya materi perkuliahan terutama terkait dengan Mata Kuliah Pengantar Teknik Industri dan Manajemen Sumber Daya Manusia.

\subsection{Manfaat Penelitian.}

a. Output penelitian tentang pengembangan komunitas pesisir dapat mendorong masyarakat untuk berusaha memanfaatkan dan memberdayakan sumberdaya alam pesisir.

b. Pengembangan komunitas pesisir local merupakan salah satu solusi untuk menigkatkan penyerapan tenaga kerja.

c. Pengembangan komunitas pesisir berbasis kearifan lokal dapat mendorong munculnya usaha lain seperti industri jasa transportasi, perdagangan, restoran.

d. Pengembangan komunitas pesisir dapat meningkatkan nilai yang pada gilirannya dapat berkontribusi terhadap PDRB dan PAD Kota Ambon.

\section{METODE PENELITIAN}

\subsection{Lokasi Penelitian.}

Lokasi Penelitian adalah Kecamatan Leitimur Selatan, Kota Ambon.

\subsection{Variabel yang diamati.}
a. Karakteristik Wilayah
b. Penyebaran Penduduk 
c. Dinamika social masyarakat

d. Kualitas kepemimpinan masyarakat

e. Pengelola usaha pesisir dan laut

f. Kualitas program pemberdayaan masyarakat

g. Perilaku masyarakat pesisir memanfaatkan SDP

h. Kesejahteraan rumah tangga

i. Ketersediaan infrastruktur dasar (air, listrik, akses transportasi dan komunikasi)

\subsection{Pendekatan Penelitian.}

a. Metode Penelitian: kualitatif, yaitu menganalisis peran anggota komunitas antara lain, nelayan, dan individi pengolah sumberv daya pesisir, dan perilaku masyarakat pesisr dalam pemanfaatan SDP.

b. Proses pengumpulan dan analisis informasi, penafsiran dan penarikan kesimpulan.

\section{HASIL DAN CAPAIAN PENELITIAN}

\subsubsection{Gambaran Umum Responden Penelitian}

Dari ke enam lokasi penelitian yang dijadikan sebagai sampel penelitian adalah tiga lokasi, masing-masing negeri Naku, Hukurilla dan Hutumuri.

Rata-rata usia responden adalah 42 tahun dengan tingkat pendidikan yang bervariasi serta pengalaman menjalankan usaha budidaya minimal diatas 10 tahun. Tingkat pendapatan pembudidaya berkisar antara Rp.500.000- Rp.700.000 perbulan itupun tergantung dari hasil panen tangkapan.

Modal yang dikeluarkan untuk melakukan budidaya di laut bebas ini sangat besar rata-rata Rp.12.500.000,-.

Usia rata-rata responden yang berperan sebagai pengolah hasil pertanian adalah 40 tahun,rata-rata tamatan SMU. Rataan pengalaman berusaha yang dimiliki olaeh pengolah adalah 12 tahun dengan pendapatan perbulan Rp.400.000-Rp.500.000,-. Hasil olahan pada umumnya hanya berupa ikan asap dan hanya dipasarkan dipusat kota Ambon.

Responden nelayan penangkap ikan konsumsi dan pengolah pemasar di tiga lokasi sampel penelitian memiliki ciri, diantaranya usia nelayan berkisar antara 32 hingga 42 tahun dengan persentase tertinggi, yaitu $73,8 \%$ di negeri Hutumuri dan Hukurilla dan 30 di negeri Naku. Tingkat pendidikan responden umunya tamat SMP dan SMA. Responden yang menyelesaikan tingkat pendidikan menengah atas adalah, $83 \%$ dinegeri Naku, $67 \%$ dinegeri Hukurilla dan $72 \%$ di negeri Hutumuri.

Berdasarkan pengalaman menjalankan usaha perikanan, 20\% responden di negeri Hutumuri memiliki pengalaman diatas 20 tahun, $35 \%$ memiliki pengalaman 10-15 tahun dan 45\% memiliki pengalaman 5-10 tahun. Di negeri
Hukurilla 5\% responden memiliki pengalaman diatas 20 tahun, $15 \%$ memiiki pengalaman 10-15 tahun dan $80 \%$ memilki pengalaman antara 5-10\%. Sementara di negeri Naku $65 \%$ responden memiliki pengalaman diatas 20 tahun, $15 \%$ memiliki pengalaman antara 10-15 tahun dan 20\% responden memiliki pengalaman anta 5-10 tahun. Dari sisi pendapatan, tampak masyarakat pesisir di negeri Hukurilla dan Hutumuri memiliki rata-rata pendapatan yang lebih tinggi di bandingkan dengan negeri/desa Naku, yakni $40 \%$ responden memilki pendapatan diatas Rp.1.000.000,-.

\subsection{Perilaku Masyarakat Pesisir Mengelola SDP.}

\subsubsection{Perilaku Masyarakat Pesisir Negeri Hutumuri}

Pengetahuan, pemahaman, dan ketrampilan responden di negeri Hutumuri tentang SDP $90 \%$ masuk dalam kriteria tinggi, $10 \%$ belum menyadari peluang untuk mengelola SDP menjadi usaha yang lebih produktif.

Kondisi social masyarakat setempat sangat beragam dan bervariasi, hal ini tampak pada variasi pendapatan nelayan yang berkisar antara Rp.300.000,00-Rp.800.000,00 per bulan. Nelayan melakukan kegiatan usaha tambahan untuk meningkatkan penghasilan yaitu dengan memanfaatkan potensi wisata bahari yang dimiliki oleh negeri/desa.

Proses pembudidayaan perikanan yang dilakukan hanya lewat pembuatan rumpong/sero. Dari data yang diperoleh 20\% rumpon/sero adalah milik nelayan sendiri dan sissanya $80 \%$ adalah milik mitra usaha.

Kesulitan lain yang dihadapi nelayan adalah keterbatasan akses layanan kredit dari lembaga keuangan formal. Kesulitan ini dapat diatasi dengan adanya bantuan pemerintah pusat lewat Program Bantuan dana Desa yang disalurkan kepada desa/negeri yang ada diseluruh pelosok nusantara.

\subsubsection{Perilaku Masyarakat Pesisir Negeri Hukurilla}

Dari segi kognitif masyarakat di negeri ini memahami potensi SDP, tetapi pemanfaatannya masih terbatas pada perikanan tangkap, dan jasa wisata bahari.

Aktifitas penangkapan ikan dilakukan oleh nelayan dengan armada motor temple, bodi pancing tunda dan bodi bobo. Pemanfaatan hasil tangkapan dilakukan oleh wanita nelayan lewat pemasaran hasil tangkapan dan ada juga yang dikelola oleh para wanita yang tergabung dalam usaha jibu-jibu. Komunitas atau kelompok pemanfaat wilayah pesisir di negeri Hukurilla responsive terhadap ide baru, hal ini tampak pada kemapuan memodifikasi berbagai alat tangkap sering dengan perkembangan 
yang ada. Disisi lain, sikap mental mengelola kawasan pemukiman di pesisir masih memerlukan perhatian terutama dalam menjaga lingkungan pantai tetap bersih, hijau dan asri, apalagi negeri/desa Hukurilla dicanangkan sebagai daerah Pusat Pengembangan Pariwisata Bahari di Kota Ambon.

\subsection{Perilaku Masyarakat Pesisir Negeri Naku}

Aktifitas penangkapan ikan dilakukan oleh nelayan dengan armada motor temple, bodi pancing tunda dan bodi bobo. Khusus bagi nelayan yang melakukan aktifitas lewat kelompok nelayan bodi bobo karena keterbatasan modal untuk pemeliharaaan maupun pengadaan sara penangkapan. Pemanfaatan hasil tangkapan dilakukan oleh wanita nelayan lewat pemasaran hasil tangkapan dan ada juga yang dikelola oleh para wanita yang tergabung dalam usaha jibu-jibu serta pengelolaan dilakukan dalam bentuk pembuatan ikan asab tapi dalam skala yang kecil.

Komunitas atau kelompok pemanfaat wilayah pesisir di negeri ini juga bersifat responsive terhadap ide baru, hal ini tampak pada kemmapuan memodifikasi berbagai alat tangkap sering dengan perkembangan yang ada. Disisi lain, sikap mental mengelola kawasan pemukiman di pesisir semakin baik . Perlu adanya dukungan fasilitas pendingin yang memadai untuk menyimpan hasil tangkapan agar tidak mudah rusak.Secara afektif, nelayan di daerah ini memiliki respons positif terhadap pelestarian terumbu karang, pemeliharaan mangrove, dan penanganan kawasan pesisir.

Proses pembudidayaan perikanan yang dilakukan hanya lewat pembuatan rumpong/sero. Tidak pemilik rumpong/sero adalah nelayan itu sendiri tetapi, pemiliknya adalah mitra usaha dengan pihak lain. Sehingga proses pembagian upah pada saat panenpun dibagi bersama dengan pemilik usaha, dan nelayan penangkap/pemanen hasil budidaya tersebut. Kesulitan lain yang dihadapi nelayan adalah keterbatasan akses layanan kredit dari lembaga keuangan formal. Kesulitan ini dapat diatasi dengan adanya bantuan pemerintah pusat lewat Program Bantuan dana Desa yang disalurkan kepada desa/negeri yang ada diseluruh pelosok nusantara.

Pelaksanaan penyuluhan secara tepat dapat membantu penyelesaian masalah. Kegaiatan penyuluhan dilakukan oleh penyuluh(dari Dinas/instansi terkait), tenaga pendamping LSM, atau pemuka masyarakat yang harus memiliki kompetensi teknis, social dan ekonomi agar dapat melaksanakan tugas sebagai pengembang masyarakat.

\subsection{Faktor Yang Berhubungan Dengan Perilaku Masyarakat Pesisir}

Perilaku masyarakat pesisir Leitimur Selatan didaerah sampel penelitian $40 \%$ memahami betul potensi SDP dan dapat memanfaatkan sebagai sumber penghidupan, $60 \%$ memahami betul potensi SDP tetapi belum mampu mengelola SDP secara optimal. Factor internal seperti kondisi social ekonomi, usia, pengalaman berusaha, dan lainnya merupakan hal yang berhubungan positif secara nyata dengan perilaku masyarakat pesisir. Faktor eksternal nelayan berhubungan positif yang nyata dengan perilaku nelayan. Hal ini berarti dalam melakukan upaya perubahan perilaku masyarakat pesisir, selain memperhatikan factor internal individu, kelompok dan komunitas, sangat perlu bagi penyuluh atau fasilitator program pemberdayaaan untuk memperhatikan dinamika social budaya, pola kepemimpinan, dan kualitas pendukung usaha perikanan.

\section{1) Dinamika Sosial Budaya Masyarakat}

Berdasarkan penelitian diketahui nilai social budaya masyarakat pada daerah sampel penelitian, masyarakat pesisir di negeri Naku mencapai skor yang paling tinggi diantara dua desa/negari lainnya yang menjadi sampel penelitian. Pada indicator peran lembaga adat dan kearifan local pengelolaan SDP, desa/negeri Hukurilla mencapai median skor tertinggi dibandingkan dua desa/negeri lainnya. Khusus untuk indicator dinamika antar hubungan anggota masyarakat, nilai skor hampir merata di tiga sampel lokasi penelitian.

2) Kearifan Lokal Masyarakat Pesisir dalam Mengelola SDP

Pada pandangan tentang karya, berdasarkan penelitian nelayan di kecamatan Leitimur Selatan memiliki kreativitas yang bervariasi. Contohnya di desa/negeri Hukurilla nelayan ada yang menawarkan jasa wisata bahari berupa penyewaan perahu bagi wisatawan. Tidak ada permasalahan yang berarti dalam konformitas dan penyimpangan terhadap aturan negeri. Masyarakat di ketiga negeri membuat aturan secara bermusyawarah dan berdasarkan tatanan hidup masyarakat adat

\section{3) Kualitas Kepemimpinan Formal}

Kualitas kepemimpinan formal pada tiga lokasi penelitian sebagian besar menyebar pada kulaitas kepemimpinan rendah dan tinggi. Peran kepemimpinan informal dimainkan oleh pemuka adat, pemuka agama dan tokoh masyarakat. Terkait dengan peran pemimpin informal dalam pengembangan komunitas pesisir di kecamatan Leitimur Selatan berbeda-beda.

\section{4) Keragaan Responden}

Indikator keragaan responden adalah terkait dengan rumah tangga nelayan, meliputi karakteristik responden tentang usia, pendidikan formal dan 
nonformal, jumlah tanggungan dan indicator lainnya.

\section{5) Kondisi Social Ekonomi Responden}

Kondisi social ekonomi yang didukung oleh sifat motivasi, dukungan sarana dan prasaran dsn manajemen usaha yang dinamis dapat meningkatkan produktifitas pemanfaat SDP. Kondisi social ekonomi yang tinggi belum dapat menjamin pemanfaatan/pengelolaan SDP yang benar. Kondisi social yang mantap yang dicirikan dari tatanan hidup masyarakat yang harmonis, seperti kepercayaan satu sama lain diperlukan dalam pengembangan dinamika social yang kuat, masyarakat tidak mudah mengalami kekacauan.

\section{6) Motivasi Berusaha}

Motivasi untu bertindak dapat dikembangkan dari dalam diri maupun dari luar melalui berbagai pendekatan. Tidak semua masyarakat pesisir di Kecamatan Leitisel berminat dalam memanfaatakan SDP, terdapat $40 \%$ berminat pada bidang usaha yang lain. Hal ini karena nelayan beelum menguasai ketrampilan dibidang perikanan dan kelautan denga baik, keterbatasan sarana dan prasarana untuk menangkap ikan, serta belum memiliki budaya bahari yang kuat dalam diri.

7) Kepribadian dan Keterlibatan dalam Kelompok Masyarakat pada lokasi penelitian memilki kepribadian nelayan yang merupakan interaksi antara factor internal dan eksternal individu. Interaksi dalam kelompok melalui komunikasi dan partisipasi sangat bermanfaat dalam meningkatkan wawasan dan keterbukaan seseorang tentang dunia yang lebuh luas. Masyarakat pesisir disini secara umum tiadak memiliki kendala komunikasi dan interaksi social dalam masyarakat.

\section{8) Aspek Gender}

Aspek gender dalam penelitian didekati dari tercapainya kesetaraan dan keadilan gender dalam pengelolaan SDP. Akses SDP umumnya didominasi oleh laki-laki atau kepala keluarga, terkait dengan eksplorasi dan eksploitasi potensi laut. Wanita nelayan aksesnya lebih terfokus pada penanganan ikan hasil tangkapan yaitu pada kegiatan pengolahan dan pemasaran..

9) Kualitas Program Pemberdayaan

Aspek proses pada program pembardayaan belum merupakan prioritas, hal ini ditunjukan pada persentase pencapaian terhadap skor maksimum yang paling rendah ( 64\%). Persentase tertinggi skor kualitas program dicapai pada materi program sebesar $82 \%$. Hal ini tergambar dari kosentrasi pemberdayaan hanya pada materi program.

Penilaian responden akan perencanaan tujuan mencapai $80 \%$ dari skor tertinggi dan hamper merata pada ketiga lokasi penelitian. Disisi lain, hasil Uji Chi-Square memperlihatkan hubungan yang nyata antara kualitas program, perencanaan dan tujuan, materi program dan kontinyuitas program pemberdayaan dengan lokasi.

10) Kualitas Pendukung Usaha

Wilayah pesisir Leitisel berada daerah pegunungan dengan topografi daerah yang cukup rumit, sehingga aspek rasportasi merupakan persoalan dalam menunjang kegiatan perikanan, ditambah dengan keterbatasan jumlah armada angkutan. Lokasi pendaratan ikan pada kecamatan Leitisel tidak ada, sehingga perlu pembangunan.

Penerapan hukum, peraturan, dan penyebarluasan informasi perikanan dilokasi peneliatian tidak berbeda satu dengan yang lainnya, masih ada dalam kategori lemah. Peraturan pemerintah tentang pemanfaatan SDP belum teralisasi dengan baik dikalangan komunitas pesisir.

\subsection{Capaian Penelitian}

Hasil penelitian menunjukan bahwa terdapat hubungan yang nyata antara keragaan individu dengan perilaku dalam mengelola SDP. Implementasi pengembangan masyarakat pesisir Leitisel menuju masyarakat yang sejahtera melalui pengelolaan SDP secara optimal dapat akselerasi dengan dibangunnya visi, dilaksanakannya misi, ditetapkannya tujuan yang jelas serta strategi penyuluhan yang tepat tentang pengelolaan SDP.

Visi, misi, tujuan dan target penyuluhan dalam kaitannya dengan pengelolaan SDP sangat penting dipahami, dijadikan motivator dalam bertindak, dan dilaksanakan dengan penuh tanggungjawab oleh segenap pemanfaat SDP, yaitu nelyan, atau komunitas pesisir lain, pemerintah, dan swasta.

Komunitas local menjalankan kegiatan perikanan yang tidak merusak lingkungan, secara ekonomi menguntungkan dan secara social mampu meningkatkan kualitas kehidupan berkeluarga, berkelompok dan bermasyarakat. Nelayan hendaknya mampu melakukan perencanaan usaha, memperkirakan hasil, menjamin terserapnya produk dipasar, dan mengawasi jalannya usaha.

\subsection{Model Pengembangan Perilaku Masyarakat Pesisir Dalam Mengelols SDP berdasarkan Kearifan Lokal}

Hasil analisis statistic membuktikan bahwa model tersebut representative untuk diterapkan (gambar 5.1). Perilaku masyarakat memiliki hubungan yang nyata dengan hampir seluruh indicator peubah bebas meliputi nilai-nilai social budaya, adat, kearifan local, peran dan gaya kepemimpinan, kondisi social ekonomi, motivasi, aspek gender, perencanaan kegiatan, sarana prasarana dan lainnya. Beberapa 
peubah tidak berkorelasi secara nyata yaitu antara perilaku pemimpin, sikap terhadap perubahan, kemampuan memotivasi, pasar dan sarana.

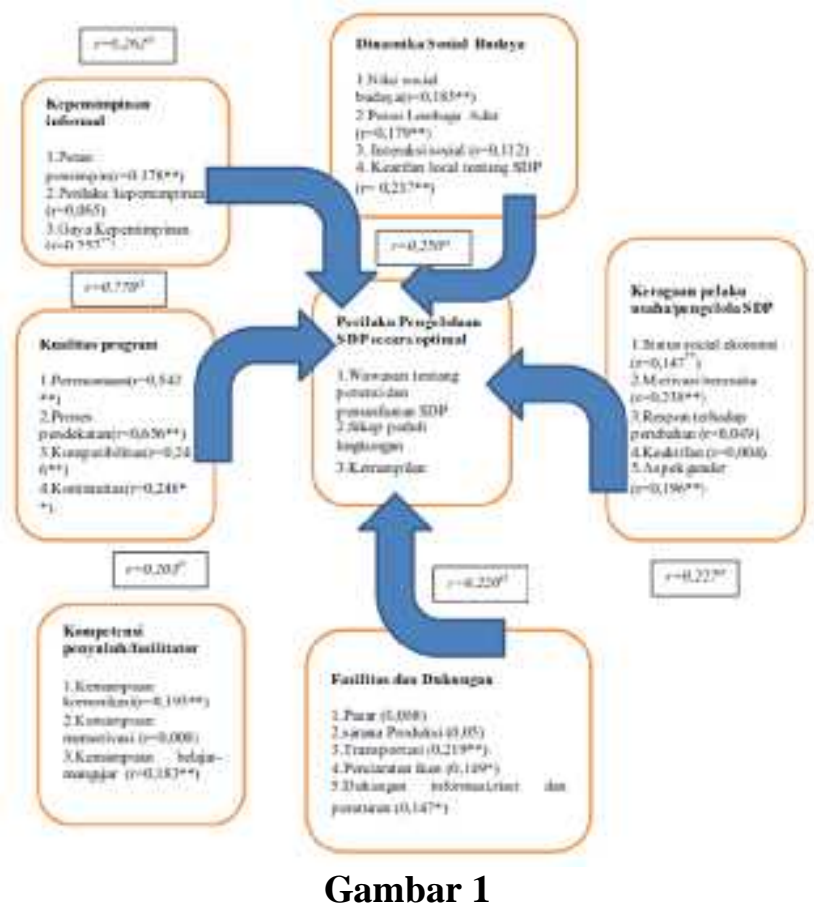

Pengelolaan SDP yang berprinsip pada keseimbangan antara tujuan social, ekonomi, dan ekologis memerlukan komitmen dari berbagai pihak, baik pemerintah maupun swasta. Luaran penelitian ini menunjukan bahwa perilaku masyarakat pesisir Leitisel dalam mengelola SDP berkorelasi positif yang nyata dengan seluruh peubah penelitian baik internal maupun eksternal. Secara sederhana system pengembangan masyarakat pesisir Leitisel digambarkan dalam gambar 5.2, memiliki tiga komponen utama yakni: system penyuluhan, system social, dan system lingkungan fisik.

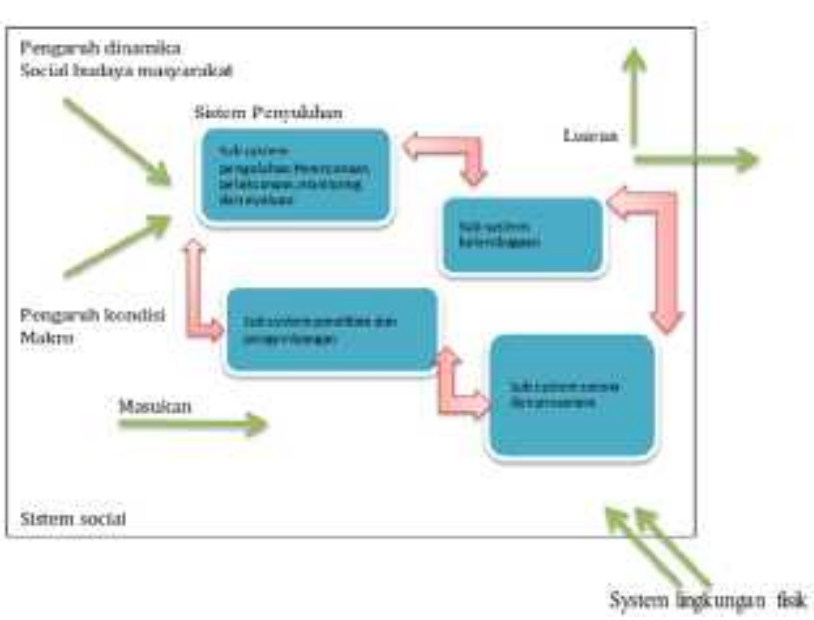

Gambar 2

\section{KESIMPULAN DAN SARAN}

\subsection{Kesimpulan}

1. Perilaku masyarakat pesisir Leitisel dalam mengelola SDP adalah sebagai berikut:

a) Pemanfaatan SDP pada ketiga sampel penelitian masih dilakukan secara tradisional.

b) Pengetahuan nelayan di Leitisel terhadap SDP bervariasi

c) Sikap masyarakat pesisir yang responsive terhadap pelestarian lingkungan pesisir.

d) Ketrampilan pengolahan ikan terbatas pada pengasapan ikan yang dilakukan oleh wanita nelayan hal ini disebabkan oleh keterbatasan modal

2. Faktor-faktor yang berhubungan dengan perilaku masyarakat pesisir dalam mengelola SDP secara optimal adalah sebagai berikut:

a) Kondisi social budaya masyarakat pesisir Leitisel yang dinamis

b) Pemanfaatan lahan pesisir untuk usaha produktif dengan tetap memperhatikan daya dukung lahan

c) Keterkaitan peubah pada model pengembangan perilaku masyarakat menunjukan adanya hubungan positif dan nyata antara dinamika social budaya, kepeimpinan formal, kondisi nelayan, kualitas program pemberdayaan, sertaa dukungan sapras pada tingkat koefisien determinasi sebesar 0,98 atau sebesar 98 persen.

d) Strategi pengembangan masyarakat pesisir Leitisel diarahkan pada peningkatan kualitas hidup nelayan dan keluarga melalui pengelolaan SDP secara terpadu.

\subsection{Saran}

1. Diperlukan pengembangan kelembagaan organisasi penyuluhan hingga level negeri/desa, dukungan sarana dan prasarana yang memadai.

2. Pengembangan perilaku yang sesuai dengan kaidah social, ekonomi dan lingkungan dalam mengelola SDP, tidak hanya diperlukan oleh masyarakat saja tapi juga untuk pihak pemerintah maupun swasta.

\section{DAFTAR PUSTAKA}

Abdul Syani (1995), Sosiologi dan Perubhan Masyarakat, Bandar Lampung Pustaka Jaya. 
Arif Satria (2000), Sosiologi Masyarakat Rangkuti, Freddy.2003. Analisis SWOT Teknik Pesisir .Jakarta PT Pustaka Cidesindo.

Boyle,Patrik G (1981), Planning Better Programs.New York:Mc,Graw Hill Book Company.

Charles Anthony T. (2001), Sustainable Fishery Systems Oxford: Blakwell Science Ltd. Membedah Kasus Bisnis.: PT Gramedia

Richard. A de FRETES (20013), Strategi Perencanaan dan pengembangan industry pariwisata, Jurnal Ilmiah Rekayasa Mesin, Media Ilmuan \& Praktisi Teknik Industri ISSN 1978-1105 Vol.1No.1 pp.14-24. 